\title{
KEBERLAKUAN YURIDIS PERATURAN PROTOKOL KESEHATAN DI PROVINSI BALI
}

\author{
I Gede Mallik Satya Devangga, I Nyoman Putu Budiartha, Ida Ayu Putu Widiati \\ Fakultas Hukum Universitas Warmadewa, Denpasar-Bali, Indonesia \\ malliksatyadevangga86@gmail.com, budiarthaputu59@gmail.com, idaayuputuwidiati@gmail.com
}

\begin{abstract}
Abstrak
Meningkatnya Covid-19 membuat pemerintah provinsi Bali mengeluarkan peraturan gubernur Bali nomor 46 tahun 2020 yang merupakan perintah dari instruksi presiden nomor 6 tahun 2020. Instruksi presiden bukanlah produk peraturan perundang-undangan maka peneliti merumuskan dua tujuan penelitian yaitu untuk mengetahui kedudukan peraturan gubernur Bali nomor 46 tahun 2020 tentang penerapan disiplin dan penegakan hukum protokol kesehatan sebagai upaya pencegahan dan pengendalian coronavirus disease 2019 dalam tatanan kehidupan era baru dalam sistem perundang-undangan di Indonesia, serta untuk mengetahui keabsahan berlakunya peraturan gubernur Bali Nomor 46 Tahun 2020 dalam sistem peraturan perundang-undangan di Indonesia Metode penelitian yang digunakan dalam penelitian ini adalah metode penelitian yuridis normatif. Berdasarkan hasil penelitian maka dapat dikemukakan bahwa peraturan gubernur Bali nomor 46 tahun 2020 berkedudukan sebagai peraturan pelaksana dari instruksi presiden sebagai produk peraturan kebijakan. Kemudian, peraturan Gubernur Bali Nomor 46 tahun 2020 tidak memiliki daya ikat seperti halnya peraturan perundang-undangan Apabila terjadi gugatan maka yang menjadi dasar pertimbangan hakim bukanlah peraturan perundang-undangan melainkan asas umum pemerintahan yang baik.
\end{abstract}

Kata Kunci: Keberlakuan Peraturan; Protokol Kesehatan.

\begin{abstract}
The increase in Covid-19 caused the Bali provincial government to issue Bali governor regulation number 46 of 2020 which is an order from presidential instruction number 6 of 2020. Presidential instruction is not a product of statutory regulations, the researchers formulated two research objectives, namely to determine the position of Bali governor regulation number 462020 concerning the implementation of discipline and enforcement of health protocol laws as an effort to prevent and control the 2019 coronavirus disease in a new era of life in the statutory system in Indonesia, as well as to determine the validity of the enactment of the Bali governor's regulation Number 46 of 2020 in the statutory system of law in Indonesia. Indonesia The research method used in this study is a normative juridical research method. Based on the results of the research, it can be argued that Bali governor regulation number 46 of 2020 is the implementing regulation of the presidential instruction as a product of policy regulations. Then, Bali Governor regulation Number 46 of 2020 does not have binding power as is the case with statutory regulations. the basis for the judge's consideration is not statutory regulations but the general principle of good governance.
\end{abstract}

Keywords: Regulatory Enforcement; Health Protocol

\section{PENDAHULUAN}

Penyebaran Covid-19 merupakan permasalahan baru yang dihadapi oleh Indonesia yang dimulai pada awal tahun 2020 meningkatnya kasus Covid-19 mengakibatkan pemerintah harus berupaya untuk mencegah penyebaran virus ini dengan berbagai cara, mulai dengan menghimbau masyarakat agar tidak keluar rumah meningkatkan disiplin masyarakat akan protokol kesehatan dan masih banyak upaya lain (Muhyiddin, 2020; Wonok, 2020). Namun himbauan saja ternyata tidak cukup untuk menertibkan masyarakat untuk mematuhi protokol kesehatan sehingga berbagai macam aturan maupun kebijakan dikeluarkan oleh pemerintah untuk meregulasi masyarakat terkait dengan protokol kesehatan Salah satu produk kebijakan yang dikeluarkan oleh presiden adalah dikeluarkannya INPRES No.6 Tahun 2020. Isi dari INPRES ini adalah memerintahkan lembaga pemerintahan lain untuk mengeluarkan peraturan terkait dengan protokol kesehatan Salah satu yang dimaksud dalam Instruksi Presiden ini adalah Gubernur yang mana Gubernur diminta untuk mengeluarkan produk aturan terkait dengan protokol kesehatan untuk menertibkan masyarakat agar selalu taat untuk menjaga 
kesehatan guna mencegah meningkatnya kasus Covid-19. Aturan mengenai penerapan protokol kesehatan di Bali dituangkan ke dalam Pergub Bali No.46 Tahun 2020. Namun mengingat daripada dasar dibentuknya Peraturan Gubernur ini adalah Instruksi Presiden yang mana Instruksi Presiden bukan lah produk peraturan perundang-undangan apabila ditinjau dari pasal 7 UU No.12 Tahun 2011, maka keberlakukan Peraturan Gubernur ini perlu dianalisa lebih dalam lagi mengenai kedudukan dan keabsahannya.

Seperti yang telah diuraikan diatas maka dapat dirumuskan dua rumusan masalah sebagai berikut : Bagaimanakah kedudukan Peraturan Gubernur Bali Nomor 46 Tahun 2020 Tentang Penerapan Disiplin Dan Penegakan Hukum Protokol Kesehatan Sebagai Upaya Pencegahan Dan Pengendalian Coronavirus Disease 2019 Dalam Tatanan Kehidupan Era Baru dalam sistem perundang- undangan di Indonesia dan bagaimanakah keabsahan berlakunya Peraturan Gubernur Bali Nomor 46 Tahun 2020 dalam sistem peraturan perundang-undangan di Indonesia.

\section{METODE PENELITIAN}

Metode yang dipakai merupakan penelitian hukum normatif dengan mengacu kepada peraturan perundang-undangan yang dianalisa dengan sistematis serta mempelajari terori-teori serta asas-asas hukum dan peraturan perundang-undangan terkait (Soekanto \& Mamudji, 2006). Teknik pengumpulan data terdiri dari teknik studi dokumen yaitu pengumpulan data dengan mencatat bahan bahan yang ada dalam literatur maupun dokumen lainnya yang membahas tentang kedudukan peraturan pemerintahan. Pendekatan masalah yang digunakan secara yuridis yaitu dengan meninjau peraturan yang berhubungan dengan permasalahan penelitian.

\section{HASIL DAN PEMBAHASAN}

\section{Kedudukan Pergub Bali No.46 Tahun 2020 dalam Sistem Perundang-Undangan di Indonesia}

Peraturan perundang-undangan merupakan kumpulan aturan tertulis yang didalamnya memuat aturan dan larangan serta dibuat oleh pemerintah yang berwenang, apabila dilanggar dapat dikenakan sanksi. Peraturan dapat dibagi menjadi tiga kelompok yaitu wettelijk regeling beleidsregels dan beschikking (Astawa \& Na'a, 2008). Di Indonesia, rantai norma serta tata urutan peraturan perundang-undangan termuat dalam UU No.12 Tahun 2011 Tentang Pembentukan Peraturan Perundang-undangan. Menurut stufenbau theorie bahwa hierarki sistem norma itu dideskripsikan sebagai berikut, yaitu: (Atmadja \& Budiartha, 2018). Norma tertinggi disebut dengan sebutan Grundnorm yang disebut juga norma hipotesis, norma dibawahnya disebut dengan dengan norma umum yang dibentuk dengan mengacu pada Grundnorm, kemudian norma yang terendah disebut dengan norma individual yang dibentuk dengan mengacu pada norma umum. Namun dalam tata urutan sisitem norma, Grundnorm tidak ditetapkan oleh otoritas karena berapa diluar tata hukum positif sehingga tidak dapat diubah.

Dalam sistem hukum Indoneia peratuan perundang-undangan berdasarkan kewenangannya dapat dibagi menjadi peraturan perundang-undangan yang berwenang sebagai kewenangan atribusi dari UUD atau UU dan ada yang namanya pearaturan perundang-undangan yang fungsinya sebagai pelaksana perintah (delegasi) dari peraturan yang lebih tinggi, peraturan ini disebut dengan peraturan pelaksana. Namun pembentukan Peraturan Gubernur tidak hanya didasari oleh pendelegasian oleh peraturan perundang-undangan Dikarenakan kedudukan dari Peraturan Gubernur sebagai peraturan pelaksana maka tidak semua Peraturan Gubernur dibentuk berdasarkan perintah dari peraturan perundang-undangan yang lebih tinggi Seperti yang dibahas disini yaitu Pergub Bali No. 46 tahun 2020 yang dibentuk berdasarkan perintah dari INPRES No. 6 Tahun 2020. INPRES bukanlah produk peraturan perundang-undangan sebagaimana termuat dalam pasal 7 dan pasal 8 UU No.12 Tahun 2012. Namun Instruksi Presiden ini dapat dikategorikan sebagai produk peraturan kebijakan yang merupakan implementasi dari asas Freies Ermessen.

Asas Freies Ermessen merupakan asas yang memberikan kewenangan kepada kepala administrasi negara dalam mengeluarkan kebijakan tanpa menggunakan dasar hukum peraturan perundang-undangan melainkan kepala administrasi negara dappat mengeluarkan kebijakan dalam kondisi negara yang gawat dengan tujuan untuk mengisi kekosongan norma. Meskipun pemerintah mempunyai wewenang bebas, namun penggunaan Freies Ermessen terdapat batasan-batasan yang harus dipatuhi. Freies Ermessen tidak diperkenankan bertentangan dengan hukum yang sedang berlaku. Penggunaan Freies Ermessen haruslah berpatokan keppada dua hal yaitu :

1) tidak diperkenankan melawan hukum yang berlaku atau dalam hal ini adalah hukum positif. 
2) hanya boleh dilakukan demi keperluan seluruh golongan masyarakat.

Freies ermessen ini digunakan terutama karena pertama kondisi darurat yang tidak memungkinkan untuk menetapkan ketentuan tertulis kedua sudah ada atau belum ada peraturan yang mengaturnya ketiga sudah ada peraturannya namun redaksinya sama atau multitafsir (Ridwan, 2009) yaitu : Freies Ermessen dapat dilaksanakan berdasarkan alasan-alasan tertentu

1) Dikeluarkannya Freies Ermessen dengan alasan belum terdapat peraturan perundang-undangan yang mengatur mengenai permasalahan tersebut dan permasalahan tersebut haruslah segera diselesaikan.

2) Dikeluarkannya Freies Ermessen sudah mendapatkan kebebasan untuk bertindak dari peraturan perundang-undangan.

3) Terdapat pendelegasian dari suatu peraturan perundang-undangan.

Freies Ermessen diwujudkan ke dalam bentuk peraturan kebijakan (beleidsregel) dengan berbagai macam format seperti yang telah disebutkan diatas. Terbentuknya peraturan kebijakan ini merupakan hal yang diperbolehkan terjadi dalam sistem pemerintahan. Adapun beberapa ciri-ciri peraturan kebijakan yang diakui dalam sistem perundanng-undangan yaitu:

1) Merupakan keputusan maupun peraturan tertulis dengan bentuk format sesuai yang telah disebutkan diatas.

2) Dikeluarkan dan dibentuk oleh pejabat administrasi negara yang mempunyai wewenang untuk mengeluarkan peraturan tersebut.

3) Didalamnya memuat aturan hukum yang mengikat secara umum dan ditunjukkan kepada orang banyak bukan terhadap individu tertentu.

4) Dikeluarkan sesuai dengan prosedur dalam peraturan perundang-undangan yang mana pembentukannya telah diatur dalam sistem perundang-undangan tertentu.

Namun dalam hal ini Presiden selaku kepala administrasi negara mengeluarkan INPRES No.6 Tahun 2020 dengan tujuan untuk mengisi kekosongan norma mengenai pengaturan protokol kesehatan Sehingga Instruksi Presiden ini tidaklah tergolong peraturan perundang-undangan. Seperti yang telah diuraian tersebut diatas maka peraturan pelaksana dari INPRES tersebut diatas yaitu Peraturan Gubernur Nomor 46 Tahun 2020 yang merupakan peraturan pelaksana dari suatu produk peraturan kebijakan (beleidsregel). Sehingga kedudukan dari Pergub ini adalah sebagai peraturan pelaksana dari sebuah produk peraturan kebijakan. Dengan itu maka Pergub ini tergolong produk peraturan kebijakan bukanlah produk peraturan perundang-undangan.

\section{Keabsahan Berlakunya Pergub Bali No. 46 tahun 2020 dalam Sistem Peraturan Perundang-Undangan di Indonesia}

Keberlakuan hukum merupakan eksistensi atau cara berada hukum berkaitan dengan kekuatan mengikatnya Cara berada hukum itu memiliki banyak aspek yang mungkin saling terkait tetapi masing-masing berbeda jadi tidak identik. Keberlakukan hukum bertumpu pada tiga nilai dasar hukum Ketiga aspek keberlakuan hukum tersebut yakni (Atmadja \& Budiartha, 2019):

1. Keberlakuan Filosofis berdasarkan nilai filosofi eksistensi atau keberadaan hukum dengan kekuatan mengikatnya karena nilai keadilan;

2. Keberlakuan Yuridis berdasarkan nilai normatif eksistensi atau keberadaannya hukum karena nilai kepastian hukum; dan

3. Keberlakuan Sosiologis berdasarkan nilai kemasyarakatan eksistensi atau keberadaan hukum Karena penerimaan masyarakat hukum berlaku efektif.

Melonjaknya kasus penyebaran Covid-19 merupakan asal mula dikeluarkannya INPRES No.6 Tahun 2020. Kondisi negara yang mulai darurat akibat melonjaknya kasus penyebaran Covid-19 membuat pemerintah harus segera mengambil kebijakan yang signifikan. Mengingat belum ada peraturan perundang-undangan yang meregulasi mengenai protokol kesehatan Covid-19 maka dikeluarkannya Instruksi Presiden ini perlu dikaji keabsahannya Melihat dari asas Freies Ermessen yang memberikan kewenangan bagi kepala administrasi negara dalam mengeluarkan produk kebijakan maka Instruksi Presiden Nomor 6 Tahun 2020 dapat dikategorikan sebagai suatu produk peraturan kebijakan yang dikeluarkan oleh Presiden selaku Kepala Administrasi Negara dalam kondisi darurat Covid-19 Hal ini merupakan implementasi dari Teori Hukum Administrasi Negara yaitu Freies Ermessen. Freies Ermessen kerap kali digunakan sebagai solusi bagi pejabat administrasi negara karena dalam pembentukannya tanpa melalui persetujuan dari lembaga parlemen, selain itu 
Freies Ermessen juga dapat memberikan keleluasaan bagi pemerintah tanpa harus memikirkan resiko dipidana. Sekalipun Freies Ermessen memiliki legitimasi sesuai dengan UU No.30 Tahun 2014 Tentang Administrasi Pemerintahan, perlu juga ditinjau mengenai pengujiannya dari kewenangan bebas tersebut dalam mengeluarkan suatu prduk peraturan.

Kekebasan bertindang pada asas Freies Ermessen terwujud dalam bentuk peraturan kebijakan (beleidsregel) berdasarkan prosedur yang ditetapkan oleh peraturan perundang-undangan. Namun Produk peraturan kebijakan juga dapat dikeluarkan tanpa ada peraturan perundang-undangan sebelumnya yang mengatur tentang hal serupa Dalam pembahasan ini adalah Instruksi Presiden Nomor 6 Tahun 2020 yang mana maksud dan tujuan dari dikeluarkannya adalah sebagai peraturan yang memerintahkan pejabat pemerintah dibawahnya agar menyusun suatu peraturan mengenai penerappan protokol kesehatan untuk mencegah terjadinya penyebaran Covid-19 Salah satu peraturan yang telah dibentuk setelah dikeluarkannya Instruksi Presiden ini adalah Peraturan Gubernur Bali Nomor 46 Tahun 2020 Yang mana Peraturan Gubernur ini disusun oleh Gubernur Bali dengan tujuan agar penyebaran Covid-9 di Provinsi Bali dapat dikendalikan. Dalam penyusunan rancangan Pergub haruslah memperhatkan ketentuan penyusunan peraturan pperundang-undangan, karena bagaimanapun juga dalam penyusunan suatu rancangan Pergub tidak boleh bertentangan dengan susunan rancangan peraturan perundangan-undangan.

Keabsahan berlakunya suatu Peraturan Gubernur dapat dilihat dari dasar pembentukan Peraturan Gubernur tersebut Apabila mengacu pada pasal 8 UU No.12 Tahun 2011 maka dapat disimpulkan Peraturan Gubernur merupakan salah satu produk peraturan yang diakui keabsahan sebagai suatu peraturan perundang- undangan sepanjang diperintahkan oleh peraturan perundangundangan yang lebih tinggi. Namun diluar daripada itu dikarenakan Peraturan Gubernur berkedudukan sebagai peraturan pelaksana maka tidak semua Peraturan Gubernur dibentuk berdasarkan perintah dari peraturan perundang-undangan yang ada diatasnya. Ada kemungkinan Peraturan Gubernur dibentuk bukan dari perintah peraturan perundang-undangan melainkan dari perintah oleh produk peraturan lain seperti halnyan Pergub Bali No.46 Tahun 2020. Adapun yang dapat menjadi perbandingan antara peraturan perundangan- undangan dengan peraturan kebijakan adalah sebagai berikut :

1) Persamaan

a) Mengikat masyarakat secara umum tanpa terkecuali

b) Kewenangan pengaturan bersumber dari wewenang yang bersifat umum dan publik

c) Dari bentuk dan formatnya acapkali sama

d) Kebutuhan negara hukum modern selama masih ada campur tangan negara dalam kehidupan masyarakat maka regulasi (peraturan perundang- undangan dan peraturan kebijakan) masih akan terus ada terus dibentuk terus diubah disempurnakan dicabut dan dibentuk lagi yang baru

2) Perbedaan

a) Peraturan perundang-undangan berumber dari fungsi legislatf dan eksekutif, sedangkan peraturan kebijakan hanya bersumber dari fungsi eksekutif.

b) Meskipun bersifat publik tetapi sumber wewenang peraturan perundang- undangan berasal dari aturan tertulis di atasnya (UU atau UUD) sedangkan peraturan kebijakan bersumber pada wewenang diskresi

c) Bentuk dan formatnya terkadang sama namun juga terkadang berbeda.

Peraturan kebijakan tidak selalu tampil susuai dengan tampilan peraaturan perundangundangan seperti biasanya. Sehingga secara yuridis Pergub Bali No.46 Tahun 2020 sah berlaku sebagai produk peraturan kebijakan (beleidsregel) bukan sebagai peraturan perundang- undangan. Sehingga keabsahan dari Pergub Bali No.46 Tahun 2020 ini tidak sama halnya dengan peraturan perundang-undangan. Lalu dari segi pengujian materinya juga berbeda yang mana apabila terjadi gugatan terhadap Peraturan Gubernur ini maka yang yang menjadi dasar pertimbangan hakim bukan lah peraturan perundang-undangan yang lebih tinggi melainkan asas umum pemerintahan yang baik. Adapun beberapa asas pemerintahan yang baik adalah sebagai berikut (Muhammad Azhar, 2015).

1) Asas Kepastian Hukum yaitu merupakan asas yang mengutamakan landasan kentntuan peraturan perundang-undangan yang dalam setiap kebijakan haruslah memiliki unsur keadilan dan kepatutan dalam setiap kebijakan yang dikeluarkan. 
2) Asas Kemanfaatan yaitu asas yang mengutamakan dari segi manfaat secara seimbang anatara kepentingan individu dengan individu, individu dengan masyarakat, masyarakat dengan masyarakat asing, kelompok masyarakat satu dengan kelompok masyarakat lain, pemerintah dengan masyarakat, generasi sekarang dengan generasi mendatang, manusia dengan alam, serta kepentingan antara pria dan wanita.

3) Asas Ketidakberpihakan dalam hal ini suatu peraturan haruslah adil dan tidak berpihak pada satu individu atau golongan tertentu.

4) Asas kecermatan mengharuskan kebijakan dan/atau tindakan harus didasarkan pada informasi dan dokumen yang lengkap untuk mendukung legalitas penetapan dan/atau pelaksanaan keputusan dan/atau tindakan sehingga keputusan dan/atau tindakan yang bersangkutan dipersiapkan dengan cermat sebelum keputusan dan/atau tindakan tersebut ditetapkan dan/atau dilakukan

5) Asas Tidak Menyalahgunakan Kewenangan yaitu setiap kebijakan yang dikeluarkan harus sesuai dengan kewenangan pejabat yang mengeluarkan dengan tidak menyalahgunakan kewenangan untuk kepentingan pribadi.

6) Asas Keterbukaan merupakan asas yang mengharuskan pemerintah untuk bersikap terbuka kepada setiap golongan masyarakat.

7) Asas Kepentingan Umum, dalam hal ini suatu kebijakan harus mendahukukan kepentingan umum diatas kepentingan pribadi.

Maka berdasarkan asas-asas yang telah dipaparkan diatas, suatu produk peraturan kebijakan hendaknyan tidak boleh bertentangan dengan asas-asas tersebut duiatas.

\section{SIMPULAN DAN SARAN}

\section{Simpulan}

Kedudukan atau Posisi Peraturan Gubernur Bali Nomor 46 Tahun 2020 merupakan produk peraturan pelaksana dari Instruksi Presiden Nomor 6 Tahun 2020 yang merupakan produk peraturan kebijakan dari Presiden Republik Indonesia selaku Kepala Administrasi Negara Hal ini dikarenakan pembentukan Peraturan Gubernur ini tidak berdasarkan pada peraturan perundang-undangan yang lebih tinggi melainkan dibentuk berdasarkan Instruksi Presiden yang dibentuk berdasarkan asas Freies Ermessen Secara yuridis Peraturan Gubernur Bali Nomor 46 Tahun 2020 sah berlaku sebagai produk peraturan kebijakan (beleidsregel) bukan sebagai peraturan perundang-undangan Sehingga tidak memiliki daya ikat atau keabsahan seperti halnya peraturan perundang-undangan dan apabila terjadi gugatan terhadap Peraturan Gubernur ini maka yang menjadi dasar pertimbangan hakim bukanlah peraturan perundang-undangan melainkan asas umum pemerintahan yang baik

\section{Saran}

Dalam melakukan penyusunan Peraturan Gubernur Gubernur Bali hendaknya selalu memperhatikan aspek keberlakuan hukum nya agar kedudukan fungsi serta keabsahannya jelas dan lebih mudah dipahami oleh masyarakat serta dalam membuat kebijakan maupun aturan hendaknya Gubernur Bali lebih mengedepankan nilai kemanfaatan dari produk peraturan maupun kebijakan yang dikeluarkan agar masyarakat lebih bisa menghargai hukum dan aturan yang berlaku

\section{DAFTAR PUSTAKA}

Astawa, I. G. P., \& Na’a, S. (2008). Dinamika Hukum dan Ilmu Perundang- undangan di Indonesia. Bandung: Alumni.

Atmadja, I. D. G., \& Budiartha, I. N. P. (2018). Teori-Teori Hukum. Malang: Setara Pers.

Atmadja, I. D. G., \& Budiartha, I. N. P. (2019). Sistematika Filsafat Hukum. Malang: Setara Pers.

Muhammad Azhar. (2015). Relevansi Asas-Asas Umum Pemerintahan yang Baik dalam Sistem Penyelenggaraan Administrasi Negara. NOTARIUS, 8(2), 274-287.

Muhyiddin. (2020). Covid-19, New Normal dan Perencanaan Pembangunan di Indonesia. The Indonesian Journal of Development Planning, IV(2), 240-252.

Ridwan. (2009). Tiga Dimensi Hukum Administrasi dan Peradilan Administrasi. Yogyakarta: UII Press.

Soekanto, S., \& Mamudji, S. (2006). Penelitian Hukum Normatif Tinjauan Singkat. Jakarta: Rajawali Pers.

Wonok, G. R. J. (2020). Strategi Pemerintah Desa dalam Pencegahan Penyebaran Virus Corona (Covid-19) (Studi di Desa Mokobang Kecamatan Modoinding Kabupaten Minahasa Selatan). Jurnal Politico, 9(1), 117. 